\title{
Sixty-Eight Cities of the United States in 1920
}

\section{Douglas C. Ridgley}

To cite this article: Douglas C. Ridgley (1921) Sixty-Eight Cities of the United States in 1920, Journal of Geography, 20:2, 75-79, DOI: 10.1080/00221342108984922

To link to this article: http://dx.doi.org/10.1080/00221342108984922

曲 Published online: 22 Feb 2008.

Submit your article to this journal

Џ Article views: 4

Q View related articles $\sqsubset$ 


\title{
SIXTY-EIGHT CITIES OF THE UNITEDSTATES IN $1920^{1}$
}

\author{
DOUglas C. RIDGLEY
}

State Normal University, Normal, Illinois

The United States Census is taken every ten years. This includes exhaustive reports concerning population, agriculture, manufactures, forestry and forest products, mines and quarries.

Preparation for taking the census of 1920 began in July, 1919, and 70,000 enumerators started their work on January 2, 1920, as January 1 fell on Sunday. Their task involved a call at every home in the land during the month of January. Inquiry was made and facts recorded concerning all the people of the United States. Detailed reports were also made concerning agriculture, manufactures, and other subjects.

In the Bureau of the Census of the Department of Commerce at Washington, D. C., hundreds of persons are engaged in studying, classifying, tabulating, and publishing the census reports. Publication of all reports will not be completed until 1922. In order to give information concerning the census returns, the Bureau of the Census issues reports from day to day to the newspapers and others who are interested. The earlier reports are concerning population. Since February, 1920 , readers have found census population facts almost daily in the newspapers.

A recent report on which this article is based gives the population of cities having 25,000 inhabitants or more. Some of the leading facts of this report are here summarized. Populations are given in round numbers.

\section{Classes of Cities, Number, and Total Population of Each Class}

\begin{tabular}{|c|c|c|c|c|}
\hline & Cities having & Number & Population & $\begin{array}{l}\text { Increase } \\
\text { per cent } \\
1910-1920\end{array}$ \\
\hline Group 1. & 200,000 inhabitants or more & 33 & $22,000,000$ & 24.8 \\
\hline Group 2. & 100,000 to 200,000 inhabitants. & 35 & $4,700,000$ & 28.8 \\
\hline Group 3. & 50,000 to 100,000 inhabitants. . & 76 & $5,200,000$ & 33.2 \\
\hline Group 4. & 25,000 to 50,000 inhabitants. . & 144 & $5,100,000$ & 34.1 \\
\hline Total & 25,000 inhabitants or more. & 288 & $37,000,000$ & \\
\hline & Total population Continental United State & & $.105,000,000$ & 14.9 \\
\hline
\end{tabular}

The 33 larger cities have about 20 per cent of the population of the United States, and the 288 cities included in the summary have 35

1 This is the first of a series of articles by Professor Ridgley based on the census reports of 1920 . The next article will deal with population by states. Fditor. 
per cent of the entire population. It is interesting to note that the first two groups of the above summary have about the same number of cities, the third group is about double the second group in number with about the same population as the second group. The fourth group is about double the third group in number with approximately the same population as the third group. Exactly one-half of the 288 cities included in the summary are in the fourth group.

\section{Cities of the 100,000 Class}

Groups 1 and 2 of the above classification are usually referred to as cities of the 100,000 class, and this article deals with these 68 cities as a single group. The material is presented in such form as to be made the basis of a few geography lessons with classes now studying the United States or who have studied the United States previously. Names of states are not given after the names of cities in the lists below. Pupils should always be required to give the name of the state after the name of the city. The cities should be located by use of wall map, maps of United States and groups of states in textbook, and in atlases. In case a name indicates well-known cities in two or more states, the state is indicated. Since each decennial census stands for ten years as the only accurate count of population, it is of real importance to get promptly from the official census significant facts, classify them, and study their larger relationships as a sure foundation for accurate comparison during the next decade.

In 1910, there were 50 cities of the 100,000 class. The 1920 list contains these 50 and 18 additional cities. During the decade every one of the 68 cities grew in population, the percentage varying from less than one-tenth of one per cent for Spokane, Washington, to 201 per cent for Akron, Ohio, and 113 per cent for Detroit, Michigan. Los Angeles, California made the next largest percentage gain with 80 per cent. The increases in number of inhabitants varied from 35 for Spokane, Washington, to 850,000 for New York City. Detroit made the next largest gain, 520,000, and Chicago next with 510,000.

Among the 50 cities of the 100,000 class in 1910,7 retain the same relative rank as in 1920. New York, Chicago, and Philadelphia still rank Nos. 1, 2, and 3 respectively. San Francisco retains rank as No. 11, Minneapolis as No. 18, Birmingham as 36, and Dayton as 43. Detroit moved from No. 9 to No. 4; Los Angeles from No. 17 to No. 10. No other of the 50 cities were advanced in rank more than 4 . Spokane moved downward in rank from 48 to 66 , Cambridge from 47 to 63 , four others moved downward in rank 10 or more. Of these 50 cities, 
7 retain the same rank, 16 advance in rank and 27 rank lower, but all have gained in population.

\section{The Sixty-Eight Cities with Populations in Round Numbers}

In the following list, the cities are arranged in order of population, the numbers indicating the rank of the city in 1920 .

1. New York City, 5,600,000. 2. Chicago, 2,700,000. 3. Philadelphia, 1,800,000. 4. Detroit, 993,000. 5. Celveland, 796,000. 6. St. Louis, 772,000. 7. Boston, 748,000. 8. Baltimore, 733,000. 9. Pittsburgh, 588,000. 10. Los Angeles, 576,000. 11. San Francisco, 508,000. 12. Buffalo, 506,000. 13. Milwaukee, 457,000. 14. Washington, 437,000. 15. Newark, 414,000. 16. Cincinnati, 401,000. 17. New Orleans, 387,000. 18. Minneapolis, 380,000. 19. Kansas City (Mo.), 324,000. 20. Seattle, 315,000. 21. Indianapolis, 314,000. 22. Jersey City, 297,000. 23. Rochester, 295,000. 24. Portland (Oregon), 258,000. 25. Denver, 256,000. 26. Toledo, 243,000. 27. Providence, 237,000. 28. Columbus, 237,000. 29. Louisville, 234,000. 30. St. Paul, 234,000. 31. Oakland, 210,000. 32. Akron, 208,000. 33. Atlanta, 200,000. 34. Omaha, 191,000. 35. Worcester, 179,000. 36. Birmingham, 178,000. 37. Syracuse, 171,000. 38. Richmond, 171,000. 39. New Haven, 162,000. 40. Memphis, 162,000. 41. San Antonio, 161,000. 42. Dallas, 158,000. 43. Dayton, 152,000. 44. Bridgeport, 143,000. 45. Houston, 138,000. 46. Hartford, 138,000. 47. Scranton, 137,000. 48. Grand Rapids, 137,000. 49. Paterson, 135,000. 50. Youngstown, 132,000. 51. Springfield (Mass.), 129,000. 52. Des Moines, 126,000. 53. New Bedford, 121,000. 54. Fall River, 120,000. 55. Trenton, 119,000. 56. Nashville, 118,000. 57. Salt Lake City, 118,000. 58. Camden, 116,000. 59. Norfolk, 115,000. 60. Albany, 113,000. 61. Lowell, 112,000. 62. Wilmington, 110,000. 63. Cambridge, 109,000. 64. Reading, 107,000.' 65. Fort Worth, 106,000. 66. Spokane, 104,000. Kansas City (Kans.), 101,000. 68. Yonkers, 100,000.

\section{Classification of the Sixty-Eight Cities}

1. Open your geography textbook at the political map of the United States. Find on the map the cities of the above list in order of rank, pronounce the name of each city and the name of the state in which it is located. If the city is not given on the map of the United States, find it on the larger map of the group of states in which it is found.

2. On an outline map of the United States, place a cross for each city, so that the two lines of the cross shall intersect at the exact location of the city. Refer to the map in your geography to make sure of the location. Near the cross place the number indicating the rank of the city.

3 . With only your outline map before you, see whether you can name all the cities promptly, giving the name of the state after the name of each city.

4. Make a table to show the following facts:

a. Number of states having 7 cities of the 100,000 class

Write the names of states followed by the names of the cities for each state. 
b. Number of states having 6 cities of the 100,000 class Write the list as under " $a$ " in each case.

c. Number of states having 5 cities of the 100,000 class

d. Number of states having 4 cities of the 100,000 class

e. Number of states having 3 cities of the 100,000 class

f. Number of states having 2 cities of the 100,000 class

g. Number of states having 1 city of the 100,000 class

h. Number of states having no city of the 100,000 class

In listing the states as above, the District of Columbia is to be considered among the list of states. The complete list therefore will consist of the names of 48 states and 1 federal district.

5 . Make a list of the groups of states as shown on the various maps of your textbook. After the name of each state-group, write the number indicating the number of cities in the group. Add your numbers and see whether the sum is 68 . Name orally the cities in each group of states, note on the map the exact position of the city, and give reasons for its location. Read in the textbook what is given about each city.

6. On a map of the United States trace the 100th meridian. This meridian divides the land surface of Continental United States into two almost equal parts. How many of the 68 cities lie west of the 100 th meridian? How many east? Give reasons for this difference.

7. Name the cities of the 100,000 class located on the Mississippi River; on the Ohio River; on the Missouri River; on the Great Lakes; on the Atlantic coast; on the Gulf coast; on the Pacific coast. What proportion of the 68 cities is included in this list?

8. Which occupations-agriculture, mining, manufacturing, commerce- tend to develop large cities? Give examples and explain.

9. How many of the 68 cities are in the 11 Western States? How many in the 8 Plateau States? In the 3 Pacific Coast States? Give reasons.

10. Select 10 cities in which you are most interested and learn all you can about their advantages of location and the reasons for their development. Use textbook, commercial geographies, encyclopedias, and other reference books.

For the Geography Class or the Arithmetrc Class

The large facts of the United States Census are of sufficient importance, significance, and permanence to warrant a careful study. The facts concerning 68 cities have great geographical significance. The real meaning of the census reports is emphasized and crystallized by 
having pupils solve arithmetical problems based on census figures. These problems may be solved as a geography lesson or an arithmetic lesson. The total population of Continental United States is $105,000,000$; of these 68 cities, $27,000,000$; of the 33 larger cities, each having 200,000 inhabitants or more, $22,000,000$; of the 35 cities having between 100,000 and 200,000 inhabitants approximately 5,000,000. The following arithmetical problems are suggestive of helpful arithmetic work based on census reports. The per cents may be expressed as a whole number and one decimal place.

1. What per cent of the population of Continental United States live:

a. In the 68 cities of the 100,000 class?

b. In the 33 cities of the 200,000 class?

c. In the 10 larger eities?

d. In New York City?

e. In Chicago?

2. New York state has a population of $10,000,000$. What per cent of this population live in New York City?

3. Illinois has a population of $6,400,000$. What per cent of this population live in Chicago?

4. Ohio has a population of $7,500,000$. What per cent live in the 7 cities of the 100,000 class?

5. Massachusetts has a population of $3,800,000$. What per cent live in its cities of the 100,000 group?

6. California has a population of $3,400,000$. What per cent live in cities of over 100,000 ?

7. Akron, Ohio, had a population in 1910 of 69,000 . Find its increase in population and its percentage of increase.

8. New York City had a population in 1910 of $4,700,000$. Find its increase in population and its percentage of increase. Explain clearly why the percentage of increase for Akron and New York City are so widely different.

9. Rhode Island has a population of 600,000 . What per cent live in Providence?

10. District of Columbia has a population of 437,000 . What per cent live in the city of Washington?

11. Study the population figures of this article and make additional problems to be solved by members of your class. Look for large and interesting comparisons. Make problems that will help the student to understand geography as well as arithmetic. 